\title{
IDENTIFIKASI METABOLIT SEKUNDER EKSTRAK ETANOL DAUN TANAMAN PETAI CINA (LEUCAENA LEUCOCHEPALA [LAMK.] DE.WIT
}

\author{
Ermi Abriyani \\ Program Studi Farmasi, Fakultas Teknologi dan Ilmu Komputer, Universitas Buana \\ Perjuangan Karawang (ermi.abriyani@ubpkarawang.ac.id)
}

\begin{abstract}
ABSTRAK
Telah dilakukan penelitian mengenai karakterisasi metabolit sekunder ekstrak etanol daun tanaman petai cina, Leucaena leucochepala [Lamk.] de.wit,. Penelitian ini bertujuan untuk mengetahui metabolit sekunder dari daun tanaman ini. Manfaat dari dilakukannya penelitian ini adalah dapat memberikan informasi mengenai metabolit sekunder dari tanaman petai cina, Leucaena leucochepala [Lamk.] de.wit. Pengidentifikasian ini dilakukan dengan empat tahap yakni, uji fitokimia tanaman, ekstraksi dengan cara maserasi, memekatkan ekstrak kemudian melakukan mengidentifikasinya. Kandungan senyawa kimia aktif dalam daun petai cina adalah alkaloid, saponin, tanin dan flavonoid. Berdasarkan hasil uji plat KLT dengan eluen etil asetat : ethanol (8:2) dihasilkan Rf 0,62 yang diperkirakan merupakan flavonoid.
\end{abstract}

Kata kunci: karakterisasi, refluks, petai cina, Leucaena leucochepala [Lamk.] de.wit

\begin{abstract}
Research has been conducted on the characterization of secondary metabolites of ethanol extract of petai cina (Leucaena leucochepala [Lamk.] de.Wit) leaves. This study aims to determine the secondary metabolites of the leave and provide the information about secondary metabolites from petai cina (Leucaena leucochepala [Lamk.] de.wit) leaves. Identification was carried out with three stages are phytochemical, extraction by maceration with $70 \%$ ethanol and identifying it. The active compounds of petai cina from ethanol extract are alkaloid, saponin, tanin and flavonoid. the results of the TLC plate with eluent ethyl acetate: ethanol (8: 2) produced Rf 0.62 which is estimated to be a flavonoid.
\end{abstract}

Kata kunci: caracterization, refluks, petai cina, Leucaena leucochepala [Lamk.] de.wit

\section{Pendahuluan}

Negara Indonesia merupakan salah satu negara yang kaya akan berbagai tumbuhan. Kayanya keanekaragaman tumbuhan di negara ini sehingga menjadikan Indonesia menghasilkan devisa hayati yang juga merupakan aset bangsa yang selalu berkembang terusmenerus secara alami. Pemanfaatan tumbuhan di Indonesia banyak digunakan sebagai obat- 
obatan herbal dan sebagai upaya mempertahankan kesehatan masyarakat. Salah satu jenis tumbuhan yang digunakan sebagai obat-obatan herbal adalah tanaman petai cina dengan menggunakan daunnya.

Tanaman petai cina merupakan salah satu tanaman tropis yang kelimpahannya cukup besar di kabupaten Karawang, Indonesia. Tanaman ini mempunyai potensi senyawa bioaktif yang dapat dimanfaatkan sebagai obat-obatan herbal. Masyarakat telah memakai daun dari tanaman petai cina sebagai obat luka dan obat bengkak (Praja, M.H., dan Oktarina, R.Z., 2016). Dari penelitian yang sudah dilakukan bahwa daun petai cina dapat menjadi obat antiinflamasi dalam pengobatan luka bengkak (Praja, M.H. dan Oktarina, R. Z., 2016) dan sebagai penyembuh luka eksisi pada mencit (Hanafi, R.W., Widiani, N dan Khikmatunnaiz, M., 2012). Berdasarkan dari hal ini maka dilakukanlah penelitian dengan mengkarakterisasi senyawa bioaktif atau senyawa- senyawa metabolit sekunder yang terkandung dalam tanaman petai cina,s Leucaena leucochepala[Lamk] de. Wit.

\section{Metode penelitian}

\section{Peralatan yang digunakan dalam penelitian;}

Peralatan yang digunakan adalah peralatan gelas yang umum dipakai pada penelitian kimia organik bahan alam, satu set alat refluks, seperangkat alat destilasi pelarut, rotary evaporator Heidolph WB 2000, oven, pompa vakum, plat KLT (Silika gel Merk 60 GF $_{254}$ ), kolom kromatografi biasa, kertas saring, lumpang porselen, pipet tetes, pipa kapiler, bejana kromatografi, Lampu UV model UV GL - 58 UV 254 dan 360 nm.

\section{Bahan yang dipakai dalam penelitian}

Sampel yang digunakan adalah daun petai cina yang dikumpulkan dari bulan Oktober sampai dengan November 2017 yang ada di area pemukiman Karawang timur, Kabupaten Karawang, Jawa barat.

Bahan lain yang digunakan adalah n-heksan, etil asetat, etanol, metanol, asam klorida p.a, aquades, serbuk magnesium, etil asetat, amoniak p.a, $\mathrm{AlCl}_{3}$, asam asetat, natrium hidroksida, asam sulfat pekat, $\mathrm{FeCl}_{3}$, natrium asetat, asam borat. Silika gel Merk $60 \mathrm{GF}_{254}(230-400$ mesh), sedangkan kromatografi lapis tipis (KLT) mengunakan plat KLT Kiessel gel $60 \mathrm{GF}_{254}$. Pereaksi Meyer digunakan untuk identifikasi alkaloid, pereaksi Lieberman Burchard untuk 
identifikasi terpenoid dan steroid, Sianoda tes untuk identifikasi flavonoid dan $\mathrm{FeCl}_{3}$ untuk identifikasi fenolik.

\section{Preparasi sampel}

Daun Petai cina dikumpulkan dari area pemukiman Karawang timur, kabupaten Karawang, Jawa Barat.

\section{Uji Fitokimia}

\section{Pemeriksaan Alkaloid}

Empat gram sampel ditambahkan $10 \mathrm{~mL}$ kloroform dan $10 \mathrm{~mL}$ ammonia. Larutan tersebut disaring ke tabung reaksi dan filtrat di tambahkan 10 tetets $\mathrm{H}_{2} \mathrm{SO}_{4} 2 \mathrm{~N}$. Campuran dikocok dan didiamkan sampai terbentuk dua lapisan. Lapisan atas dipindahkan ke dalam tabung reaksi yang masing-masing diisi $\pm 1 \mathrm{~mL}$. Kemudian ditambahkan pereaksi Mayer, jika didapatkan endapan putih mengindikasikan adanya alkaloid dalam sampel

\section{Pemeriksaan Flavonoid}

Pemeriksaan flavonoid digunakan metoda Sianidin test, sebanyak 5 gram sampel tanaman petai cina yang sudah dihaluskan ditambah $20 \mathrm{ml}$ methanol, kemudian dididihkan dan disaring selagi panas. Ambil ekstrak methanol dan uapkan, setelah kering residu dilarutkan dengan etil asetat dan disaring. Filtratnya diuapkan dan sisanya dilarutkan dalam etanol, kemudian tambahkan asam klorida pekat dan bubuk magnesium, terbentuknya warna orange sampai merah menunjukkan adanya flavonoid (kecuali untuk flavon).

\section{Pemeriksaan Saponin}

Bahan simplisia dan ekstrak1 g ditambahkan $100 \mathrm{ml}$ air panas, dididihkan selama 15 menit kemudian disaring. Filtrat sebanyak $10 \mathrm{ml}$ dalam tabung reaksi dikocok 205ellucid selama 10 detik dan diamkan selama 10 menit. Bahan positif mengandung saponin bila terbentuk buih yang mantap selama tidak kurang dari 10 menit setinggi $1 \mathrm{~cm}$ dan buih tidak hilang ketika ditambah $\mathrm{HCl} 2 \mathrm{~N}$.

\section{Pemeriksaan Tanin}

Bahan simplisia dan ekstrak $1 \mathrm{~g}$ ditambahkan $100 \mathrm{ml}$ air panas, dididihkan selama 15 menit kemudian disaring. Filtrat sebanyak $5 \mathrm{ml}$ direaksikan dengan larutan $\mathrm{FeCl}_{3} 1 \%$. Dalam tabung lain, $5 \mathrm{ml}$ sampel ditambahkan larutan gelatin. Bahan positif mengandung tannin jika 
timbul warna hijau violet pada penambahan $\mathrm{FeCl}_{3}$ dan terbentuk endapan pada penambahan larutan gelatin.Untuk pemeriksaan tannin galat dan katekat dilakukan dengan cara berikut. Filtrat ditambahkan pereaksi Steasny, kemudian dipanaskan dalam tangas air. Bahan positif mengandung katekat jika terbentuk endapan merah muda.

\section{Pemeriksaan Steroid dan terpenoid}

Bahan simplisia dan ekstrak1 gram dimaserasi dengan $25 \mathrm{ml}$ eter selama 2 jam kemudian disaring. Filtrat sebanyak $5 \mathrm{ml}$ diuapkan dalam cawan penguap, kedalam residu ditambahkan 2 tetes asam asetat anhidrat kemudian ditambah 1 tetes asam sulfat pekat. Bahan positif mengandung steroid/triterpenoid jika terbentuk warna ungu - biru/hijau.

\section{Ekstraksi}

Sebanyak 250 gram serbuk kering petai cina (Leucaena leucochepala [Lamk.] de.Wit.,) dimaserasi dengan etanol. Selanjutnya disaring dan ditampung dalam beaker glass. Kemudian ekstrak dipartisi dengan n-heksana. Setelah dingin diuapkan pelarutnya dengan penguap vakum pada suhu $40^{\circ} \mathrm{C}$ sampai diperoleh ekstrak kental dari masing-masing pelarut tersebut.

\section{Hasil Dan Pembahasan}

Ekstrak yang dihasilkan dari 250 gram serbuk petai cina dengan maserasi memakai pelarut etanol adalah 5,25 gram. Kemudian dilanjutkan untuk uji fitokimia dan uji plat KLT.

\section{Uji Fitokimia}

Berdasarkan dari uji fitokimia ekstrak daun petai cina, didapatkanlah hasilnya sebagai berikut;

Tabel 1. Hasil uji fitokimia daun

\begin{tabular}{|l|l|l|c|}
\hline No. & Kandungan Kimia & Pereaksi & Hasil Uji \\
\hline 1. & Flavonoid & Sianidin test & + \\
\hline 2. & Fenolik & $\mathrm{FeCl}_{3}$ & + \\
\hline 3. & Saponin & $\mathrm{H}_{2} \mathrm{O}$ & + \\
\hline 4. & Terpenoid & Liebermann-Burchard (LB) & + \\
\hline 5. & Steroid & Liebermann-Burchard (LB) & + \\
\hline
\end{tabular}




\begin{tabular}{|l|l|l|c|}
\hline 6. & Tanin & $\mathrm{FeCl}_{3}$ & + \\
\hline 7. & Alkaloid & dargendorff & - \\
\hline
\end{tabular}

Keterangan : $(+)=$ ada, $(-)=$ tidak ada

Dari data diatas dapat diketahui bahwa daun dari tanaman petai cina tergolong sebagai tanaman yang cukup berpotensi karena mengandung senyawa metabolit sekunder yaitu flavonoid, fenolik, saponin, terpenoid, steroid, tanin dan fenolik.

Berdasarkan dari perlakukan dengan plat KLT menggunakan eluen etil asetat ; ethanol (8 : 2) maka spot dari pengujiannya adalah seperti gambar. Spot tersebut diamati dengan menggunakan lampu UV dekat dengan Rf 0,62. Dari hasil pengujian dengan menggunakan plat KLT tersebut diperkirakan spot yang terlihat adalah golongan flavonoid.

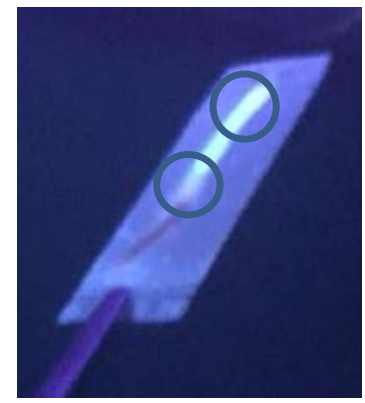

Gambar 1. Hasil uji Plat KLT ekstrak ethanol

\section{Penutup}

Berdasarkan dari hasil penelitian dapat disimpulkan bahwa tanaman petai cina (Leucaena leucochepala [Lamk.] de.Wit.), mengandung metabolit sekunder flavonoid, tanin, fenolik, saponin, terpenoid dan steroid yang di uji dengan beberapa pereagen yang sesuai. Dari hasil pengujian dengan plat KLT dengan Rf 0,62 diperkirakan senyawa yang dihasilkan metabolit sekunder flavonoid.

\section{Daftar pustaka}

Ardhi. Tanaman obat: manfaat atau khasiat petai cina (Leucaena glauca). Bandung: Sentra Informasi Iptek \& Digital Library ITB; 2010.

Bussman, R. W., Glenn, A., Sharo, D., 2010, Antibacterial Activity of Medical Plants of Northen Peru - Can Traditional Applications Provide Leads for modern Science?, Indian J. of Traditional Knowledge, 9(4): 742-743.

Chanwitheesuk, A., Teerawutgulrag, A., Rakariyatham, N., 2005, Screening of Antioxidant Activity and Antioxidant Compounds of Some dible Plants of Thailand, J. Food Chemistry, 92 : 491-497. 
Nhereraa, F.V., Ndlovua L.R. dan Dzowelab, B.H., 1998, Utilisation of Leucaena diversifolia, Leucaena esculenta, Leucaena pallida and Calliandra calothyrsus as nitrogen supplements for growing goats fed maize stover, Animal Feed Science and Technology, 74: $15-28$.

Praja, M.H. dan Oktarina, R. Z., 2016, Uji Efektivitas Daun Petai Cina (Laucaena glauca) Sebagai Antiinflamasi Dalam Pengobatan Luka Bengkak ., Majority, Volume 5, Nomor 5.

Radji, M., 2005, Peranan Bioteknologi dan Mikroba Endofit dalam Pengembangan Obat Herbal, Majalah Ilmu Kefarmasian, 3 : 113-126.

Rahmawati I., 2014, Perbedaan efek perawatan luka menggunakan gerusan daun petai cina (Leucaena glauca, benth) dan povidon iodine $10 \%$ dalam mempercepat penyembuhan luka bersih pada marmut (cavia porcellus). Jurnal Wiyata ;1 (2): 78-92.

Sartinah, A., Astuti, P., Wahyuono,S ., 2010, Isolasi dan identifikasi senyawa antibakteri dari daun petai cina (leucaena leucocephala (Lam.) De wit.), Majalah Obat tradisional; 15(3), 22-28.

Saucedo, G., Alvarez, Jimenez dan Arriaga., 1980, Leucaena leucocephala as a Supplement for Milk Production on Tropical Pastures with Dual Purpose Cattle, Trop Animal Product, 5: 1

Skerman, P.J., 1977, Tropical Forage Legumes, FAO: Plant Production and Protection Series No. 2.

Wahyuni, 2006, Efek Antiinflamasi Infusa Daun Petai Cina pada Tikus Jantan Galur Wistar, Skripsi, Fakutas Farmasi UMS, Surakarta. 